\title{
鳥類の宿主防御ペプチドの多様性
}

\author{
石毛 太一郎 \\ 東京農業大学生物資源ゲノム解析センター＼cjkstart東京都世田谷区桜丘 $1-1-1$

\section{Diversity of Avian Host defense peptide}

\begin{abstract}
Taichiro Ishige
Nodai Genome Research Center, Tokyo University of Agriculture Sakuragaoka 1-1-1, setagaya-ku, Tokyo
\end{abstract}

\section{はじめに}

宿主防御ペプチド（Host defense peptide; HDP）は、 別名抗菌ペプチドとも呼ばれ、病原微生物の感染から 宿主を守るための自然免疫としての生体防御機構の 1 つで、細菌から脊椎動物、さらには植物にわたる幅広 い生物種で報告されている（Cuperus ら 2013）。抗菌 ペプチドの活性はそのアミノ酸配列およびその配列に 基づく立体構造に依存し、微生物、真菌、原虫および 一部のウィルスに対してかなり広範囲な活性を示す。 HDP の直接のターゲットは微生物の細胞膜であり、 HDP が静電相互作用により強く結合することにより、 膜の流動性を劇的に変化させたり膜破壞を起こしたり することにより、抗菌あるいは殺菌作用を発揮する。 さらに、HDP はサイトカインの調節や免疫活性など の広範囲の免疫調節を有するものもある。病原微生物 への一次防御機構の役割に加え、感染部位での炎症の 抑制、樹状細胞の成熟化など獲得免疫の橋渡し的な役 割にも関与し、さらに、腫瘍細胞への細胞傷害活性も 報告されている。近年、薬剂耐性菌や世界中で流行し ている感染症を引き起こす微生物などに対して、HDP はこのような問題を解決するための抗菌薬として期待 されている。また、その多様性が疾患感受性に関わって いることが明らかになっており、その多様性を調べるこ とは抗病性育種を考える上で重要と考えられている。

本稿では、まずHDPの簡単な解説から始め、次に我々 が鳥類において主要な HDP と考えている 4 種の HDP について、その機能と我々の研究を例に紹介する。

\section{HDP の特徵と機能}

\section{1-1. 特徵}

HDP は抗菌ペプチドと呼ばれていたこともあり、 その主な特徵は抗菌作用を有するぺプチドで、微生物 にも確認されていることから進化的にも強く保存され た生体防御システムである。非常に多くの生物から HDP は同定されており、人工的に作られたものも合 わせると約 10,000 個の HDP が知られている。

一方で、HDP はそのファミリーごとに特徵的なモ チーフは存在するが、コンセンサス配列は存在しない。 しかし、扔扔まかな特徴として、1.100アミノ酸残 基以下であること（多くは12 59 アミノ酸残基）、2. 塩基性アミノ酸を豊富に含むために生理的条件下では 正電荷となること、3. $\alpha$ ヘリックス構造および $\beta$ シー 卜構造をとり、親水性アミノ酸領域と踈水性アミノ酸 領域を併せ持つ両親媒性構造（水にも脂質にも親和性 を持つ）を形成することなどの特徵を持つ。また、短 いが故に、アミノ酸置換により、HDP の活性が大き く変化する場合がある。このため、上記のような特徵 を有する既知タンパク質の中には、抗菌活性を示すこ とが報告されているものもある（Harwig ら 1995; El ら 2008)。

\section{1-2. 抗菌活性}

最も基本的な HDP の活性は、病原微生物の細胞膜 を破壊することである（図 1）（Epand とVogel 1999）。 正に荷電した HDP は、病原微生物の細胞壁を透過し、 酸性リン脂質が多く存在し、負に带電している微生物 の細胞膜に静電気的に結合し抗菌または殺菌作用を示

連絡先 : 石毛太一郎 東京農業大学生物資源ゲノム解析センター 干 156-8502 東京都世田谷区桜丘 $1-1-1$

(e-mail : t3ishige@nodai.ac.jp) 

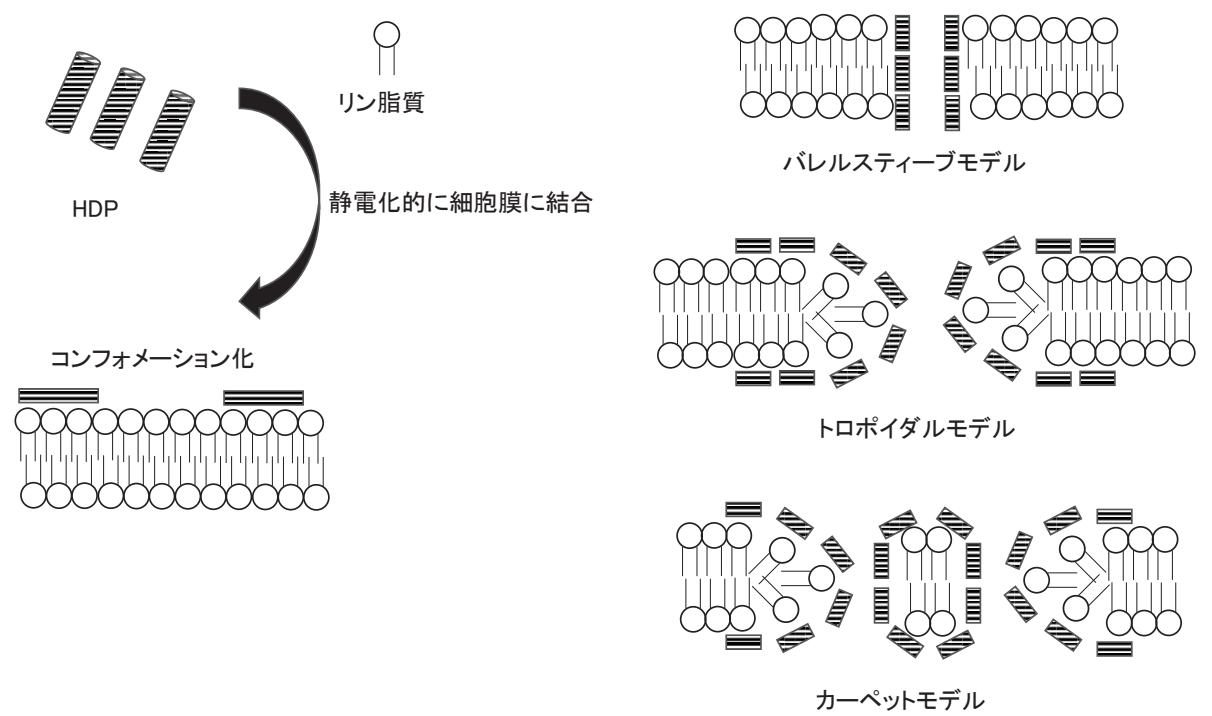

図 1 HDPによる抗菌活性の模式図。HDP は正に荷電したアミノ酸を多く有し、総電荷も正である。一方で、微生物は負に荷 電しているため、細胞壁を通り抜け静電化的に細胞膜に結合する。細胞膜に結合した HDP はやがて、バレルスティーブモ デル、トロポイダルモデル、カーペットモデルといったいくつかの方法により細胞膜と相互作用し、膜を穿孔することで 抗菌活性を発揮する。

す（Hancock 2001）。一方で、特定の HDP は、細胞膜 の構成物（リポ多糖やペプチドグリカン）に特異的に 結合することにより細胞膜を破壊する。また、HDP の中には細胞内分子に結合し、これを破壊するものも ある。しかし、中性リン脂質に富んだ宿主細胞膜や膜 安定化作用のあるコレステロールが存在する赤血球膜 への結合性は弱いといった特徵がある。HDP の構造 は、 $\alpha$ ヘリックス構造、 $\beta$ シート構造、 $\alpha$ ヘリックス 構造および $\beta$ シート構造の両方を形成するものに分か れる。どの夕イプも水溶性であり、 $a$ ヘリックス構造 の HDP は、溶液中ではランダムコイルで存在し、細 胞膜と相互作用をすることによって、疎水性抢よび親 水性アミノ酸残基がそれぞれヘリックスの片面に偏る 両親媒性のヘリックス構造を取るのが特徵である。 $\beta$ シート構造の HDP はペプチド分子内に含まれる複数 のシステイン残基の間でジスルフィド結合を形成し、 これにより構造が安定する。

HDP の抗菌活性の機序は、バレルスティーブモデ ル、トロポイダルモデルおよびカーペットモデルとし て知られている3つが仮定されている（図 1)。(1)バ レルスティーブモデルは、HDP の疎水性領域が微生 物の細胞膜の脂質 2 重層に付着し、付着した HDP 同 士が細胞膜の脂質 2 重層を中心に束ねられるように凝 集する。これにより、微生物の細胞膜に小さな孔が形 成され、細胞内容物が流出し微生物を死に至らしめる モデルである（図 1)。(2卜ロポイダルモデルでは、 HDP の極性領域と微生物の脂質の極性を持った部位
が結合し、HDP のら旋構造の部分が微生物の細胞膜 に入り込み、HDP の親水性領域と細胞膜の脂質の極 性を持った部位が共に細胞膜の中心に入り込んでくる ために湾曲し、小さな孔を形成する。但し、バレルス ティーブモデルと異なり、HDP と脂質は常時結合す る。これにより、細胞内容物が流出し微生物を死に至 らしめるモデルである（図 1)。(3)カーペットモデル では、HDP の疎水性領域（正電荷）が微生物の細胞 膜の陰イオン性の脂質層の表面に付着し、カーペット を敷いたように覆い、HDP は界面活性剂のように脂 質層を破壞し、湾曲させ、最終的に脂質層を HDP が 完全に覆ったミセル構造が形成される。これにより、 細胞内容物が流出し微生物を死に至らしめるモデルで ある（図 1）。

\section{1-3. 免疫調節}

HDP の主要な活性は、抗菌活性であるが、炎症調 節または病原体毒素の中和へも影響を与える (Mahlapuu ら 2016)。HDPによってもたらされる広範 囲の免疫調節には、走化性刺激、免疫細胞分化および 獲得免疫への惹起、Toll 様受容体（TLR）および（ま たは）サイトカインを媒介とした炎症性サイトカイン 産生の抑制㧍よび抗エンドトキシン活性などが含まれ る。また、敗血症を含む過剩抒よび有害な炎症促進反 応を防ぐことも知られている（Mahlapuu ら 2016）。実 は、こちらの機能が重要と考えている研究者もいる。 
表 1 .宿主防御ペプチドの概要

\begin{tabular}{|c|c|c|c|c|c|c|c|c|c|c|c|c|c|c|c|}
\hline & \multicolumn{8}{|c|}{$\begin{array}{l}\text { 種 } \\
\end{array}$} & \multicolumn{5}{|c|}{ 活性 } & \multicolumn{2}{|c|}{ 遺伝子変異 } \\
\hline & $\begin{array}{l}\text { 細 } \\
\text { 菌 }\end{array}$ & $\begin{array}{l}\text { 植 } \\
\text { 物 }\end{array}$ & $\begin{array}{l}\text { 昆 } \\
\text { 虫 }\end{array}$ & $\begin{array}{l}\text { 魚 } \\
\text { 類 }\end{array}$ & $\begin{array}{l}\text { 両 } \\
\text { 生 } \\
\text { 類 }\end{array}$ & $\begin{array}{l}\text { 爬 } \\
\text { 虫 } \\
\text { 類 }\end{array}$ & 鳥 & $\begin{array}{l}\text { 哺 } \\
\text { 乳 } \\
\text { 類 }\end{array}$ & $\begin{array}{l}\text { 真 } \\
\text { 囷 }\end{array}$ & $\begin{array}{l}\text { 原 } \\
\text { 生 } \\
\text { 動 } \\
\text { 物 }\end{array}$ & $\begin{array}{l}\text { グ } \\
\text { ラ } \\
\text { 茂 } \\
\text { 陽 } \\
\text { 性 } \\
\text { 菌 }\end{array}$ & $\begin{array}{l}\text { グ } \\
\text { ラ } \\
\text { 台 } \\
\text { 陰 } \\
\text { 性 } \\
\text { 菌 }\end{array}$ & $\begin{array}{c}\text { ウ } \\
\text { イ } \\
\text { ル } \\
\text { ス }\end{array}$ & $\begin{array}{l}\text { 二 } \\
\text { 塩 } \\
\text { 基 } \\
\text { 多 } \\
\text { 型 }\end{array}$ & $\begin{array}{l}コ \\
\text { ピ } \\
\text { l } \\
\text { 数 } \\
\text { 多 } \\
\text { 型 }\end{array}$ \\
\hline $\begin{array}{l}\text { NK-lysin } \\
\text { LEAP-2 }\end{array}$ & & & & & & & & $\cup$ & & & & 0 & 0 & $\mho$ & 0 \\
\hline $\begin{array}{l}\text { Cathelicidin } \\
\text { Defensin }\end{array}$ & 0 & 0 & O & 0 & $\cap$ & 0 & $\cap$ & 0 & 0 & & 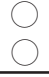 & 0 & 0 & 0 & $\rho$ \\
\hline
\end{tabular}

\section{2. 鳥類の主要な 4 種の HDP の多様性}

HDP は多細胞生物の進化に伴い、極めて多様性に 富む分子群を構成するようになり、ヒトなどでは、染 色体上でクラスターを形成する cathelicidin 遺伝子領 域扔よび defensin 遺伝子領域が知られている。このう ち、本稿では鳥類（主にニワトリ）でもその存在が確 認され、機能㧍よび含有量等の点から主要な HDP と 考えられている (Cuperus ら 2013) Granulysin/NK-lysin (以下 NKL と記載)、Liver expressed antimicrobial peptide 2 (以下 LEAP-2 と記載)、Cathelicidin（以下 CATH と記載) ならびにAvian $\beta$-defensin（以下 $\mathrm{AvBD}$ と記載）の 4 群の HDP（表 1）について解説し たいと思う。

\section{2-1. NKL}

NKL は、脊椎動物特有の HDP とされ、新しい夕イ プの HDP とされ（Bruhn ら 2003）、他の HDP と異な り球状の 3 次元構造をとる（Kim ら 2016）。NKL の構 造は、 $\alpha$ ヘリックス構造および $\beta$ シート構造の両方を 形成し、3 組のジスルフィド結合を有する。NKLは、 赤痢アメーバ (Entamoeba histolytica) のアメーバポア と同様にサポシン様タンパク質ファミリーの一員で ある（Bruhn ら 2003）。ほ乳類の NKL は、ブタ小腸由 来のナチュラルキラー（NK）細胞および細胞傷害性 Tリンパ球の顆粒から初めて分離され (Andersson ら 1995)、NK 細胞および細胞障害性 $\mathrm{T}$ 細胞の顆粒に局 在している (Peña と Krensky 1997)。その後、ナマズ (Wang ら 2006)、ウマ (Davis ら 2005)、ウシ (Endsley ら 2004）およびニワトリ（Hong ら 2006）を含む様々 な生物種での分離が報告されている（表 1)。NKL は、 グラム陰性・陽性菌、真菌抒よび一部のウィルス (Andersson ら 1995; Stenger ら 1997; Ochoa ら 2001; Ma ら 2002）に対する活性に加えて抗腫瘍活性を示す（表 1）（Ernst ら 2000; Takamori ら 2005)。NKL は、走化性 因子として、単球の活性および炎症性分子の産生など
免疫系の活性にも寄与する（Deng ら 2005）。また、 ブタ (Andersson ら 1995)、ウシ（Endsley ら 2004）、 ニワトリ（Lee ら 2012）の NKL には非同義置換が報 告され、アミノ酸置換による実効電荷の差が抗菌活性 に影響を与えることが示唆されている。ウシ NKLで はコピー数多型 (CNV) が報告され、感染防御能を 高めるためにコピー数の増加が起こったのではないか と考えられている（表 1）（Chen ら 2015）。

鳥類の NKL には、ニワトリNKL（GgNKL）（Hong ら 2006)、シチメンチョウ NKL (MgNKL) (Dalloul ら 2010） ゼブラフィンチ NKL（TgNKL）（Warren ら 2010）およびニホンウズラ NKL（CjNKL）（Ishige ら 2014）が報告されている。鳥類の NKL は、他の脊椎 動物の NKL と同様に抗菌活性（グラム陰性・陽性菌 およびコクシジウム）および腫瘍細胞に対する傷害活 性を示す (Hong ら 2006; Lee ら 2012)。GgNKL の Helix 2-loop-helix 3 構造は、抗菌活性に重要な領域 (antimicrobial region: 30 31 aa、Lee ら 2012) である。 多様性解析はニワトリでのみ報告され（Lee ら 2012）、 白色レグホーンおよびコーニッシュにより実施され た。その結果、抗菌活性領内の N29D のアミノ酸置換 を引き起こす $271 \mathrm{~A}>\mathrm{G}$ の塩基置換が確認されている。 A 対立遺伝子の頻度は、白色レグホーンで 0.89、コー ニッシュで 0.52 となり、系統間でその対立遺伝子頻 度が異なる。アミノ酸置換 N29D は NKL の実効電荷 を変化させるが、構造などには影響を与えず、29Nは 29D に比べ、グラム陰性・陽性菌の抗菌活性䇽よび抗 腫瘍活性が高い傾向が確認され、実効電荷が NKL の 活性には重要であると示唆されている（Lee ら 2012）。

我々の研究では 6 系統・99 個体を用いた CjNKLの 多様性解析により、ニワトリと同様に G31D のアミノ 酸置換を確認した（Ishige ら 2016a）。このアミノ酸置 換は実効電荷に影響を与え（31G:2.9、31D:1.9）、さら に、これが大腸菌への抗菌活性に影響を与えることを 確認し（表 2)、ニワトリと同様に実効電荷が抗菌活 
表 2 、Cj31D、Cj31G、Gg29N および Gg29D に対するグラム陰性菌である大腸菌 の生存 $(\%)$

\begin{tabular}{lrrrc}
\hline & \multicolumn{4}{c}{ ペプチド濃度 $(\mu \mathrm{M})$} \\
\cline { 2 - 5 } ペプチド(実効電荷) & 1 & 10 & 100 & 1000 \\
\hline Cj31D (1.9) & $95 \pm 15.1$ & $111 \pm 5.9$ & $112 \pm 2.8^{\mathrm{d}}$ & $14 \pm 1.8^{\mathrm{b}}$ \\
$\mathrm{Cj} 31 \mathrm{G}(2.9)$ & $102 \pm 9.0$ & $117 \pm 3.3$ & $35 \pm 2.8^{\mathrm{b}}$ & $0^{\mathrm{a}}$ \\
$\mathrm{Gg} 29 \mathrm{D}(2.9)$ & $94 \pm 2.8$ & $94 \pm 5.8$ & $99 \pm 6.1^{\mathrm{c}}$ & $0^{\mathrm{a}}$ \\
$\mathrm{Gg} 29 \mathrm{~N}(3.9)$ & $102 \pm 6.2$ & $95 \pm 5.0$ & $0^{\mathrm{a}}$ & $0^{\mathrm{a}}$ \\
\hline
\end{tabular}

$\mathrm{a}<\mathrm{b}<\mathrm{c}<\mathrm{d}$ の順で有意差あり

各值は平均值士標準誤差で示した

性に影響を与えることを確認した。また、興味深いこ とにCjNKL31G と GgNKL29D は、実効電荷が同值で あるにも関わらず、ペプチド濃度が $100 \mu \mathrm{M}$ の際に、 CjNKL31Gの抗菌活性が有意に高いことが判明した (表 2)。これは、実効電荷だけでなくそのアミノ酸配 列の構成の違いが抗菌活性に影響を与えたためと示唆 された。

\section{2-2. LEAP-2}

Liver expressed antimicrobial peptide (LEAP) は、シ ステインリッチペプチドの一種として報告されている (Cuperus ら 2013)。さらに、LEAP は、ジスルフィド 結合のペア数が 4 つの場合にLEAP-1、ペア数が $2 つ$ の場合にLEAP-2 に分類される (Cuperus ら 2013)。 LEAP-1 については鳥類で報告されていないため割愛 する。LEAP-2 は、シグナルペプチド、プレドメイン および成熟ペプチドからなる。LEAP-2 は、硬骨魚類、 爬虫類、鳥類㧍よびほ乳類で報告されている（表 1) (Cuperus ら 2013)。

LEAP-2 は、2003 年にヒト血中で抗菌活性を有すぺ プチドとして同定された（Krause ら 2003）。LEAP-2 の構造は、 $\alpha$ ヘリックス構造および $\beta$ シート構造の両 方を形成し、 2 つのジスルフィド結合を有すペプチド である。LEAP-2 は、他の HDP と同様に細胞膜を直接 破壊する（Townesら 2009）ことにより、グラム陰性・ 陽性菌を殺菌する（表 1）（Krause ら 2003; Liu ら 2010; Li ら 2015)。加えて、LEAP-2 は、微生物のゲノム DNA の加水分解により抗菌活性を仲介する（Li ら 2015)。しかし、LEAP-2 の免疫調整機能は報告されて いない。ヒトおよびウシでは成熟ペプチド内に活性に 影響を与えると予測される非同義置換が NCBI の一塩 基多型（SNP）のデータベースである dbSNPに登録 されているが、その機能への影響は調べられていない。

一方で、鳥類の LEAP-2 にはニワトリを含めた 46 種類が報告されている。鳥類の LEAP-2 は、他の脊椎 動物と同様に、グラム陰性菌に抗菌活性を示す
(Townes ら 2009)。ニワトリのみで、NCBI の dbSNP に活性に影響を与えると予測される非同義置換が登録 されている。また、ニワトリの小腸では GgLEAP-2 の $100 \mathrm{bp}$ のスプライスバリアントが報告され、21-65 番 目のペプチド断片が確認されている（Townes ら 2009)。

我々の研究で、ニホンウズラの LEAP-2 の抗菌活性 領域は、驚くべきことにニワトリのある対立遺伝子の それと完全に一致していた。また、他の鳥類とそのア ミノ酸配列を比較したところ、70\%以上の類似性を示 し、成熟ペプチドのアミノ酸配列について特定の部位 に打ける塩基もしくはアミノ酸の保存性（もしくは出 現頻度）を視覚化するシーケンスロゴを作成しても種 を超えて高い保存性があることが確認された。さらに、 99 個体の LEAP-2 抗菌活性領域の多様性解析により、 成熟ペプチド内にはアミノ酸置換どころか塩基配列の 多型すら確認されなかった。つまり、ニホンウズラの LEAP-2 は抗菌活性だけでなく、何らかの恒常性維持 にも必須であり、非常に高い保存性を維持していると 示唆された（Ishige ら 2016c）。

\section{2-3. CATH}

CATH は魚類、両生類、爬虫類、鳥類およびほ乳類 で報告されている（表 1）（Ageitos ら 2016）。しかし、 ウサギおよび䛚歯目などの真主䛚上目打よびイヌ抏よ びネコなどの食肉目では、報告されていない（表 1)。 また、多くの生物種で CATH は defensin と同様に常染 色体上にクラスターを形成している。CATH は、名前 の由来の通り N末にカセリン様ドメインを持つ(Zhang と Sunkara 2014)。CATHのN 末にあるシグナルペプ チドおよびカセリン様ドメインは種を超えて保存性が あり、C末は種により多様性がある。シグナルペプチ ドは、分泌される前に切断され、カセリン様ドメイン も放出される前にセリンプロテアーゼにより切断され る (Cuperus ら 2013)。CATH の構造は $a$ ヘリックス構 造を有する正に荷電したペプチドである。CATH は、 


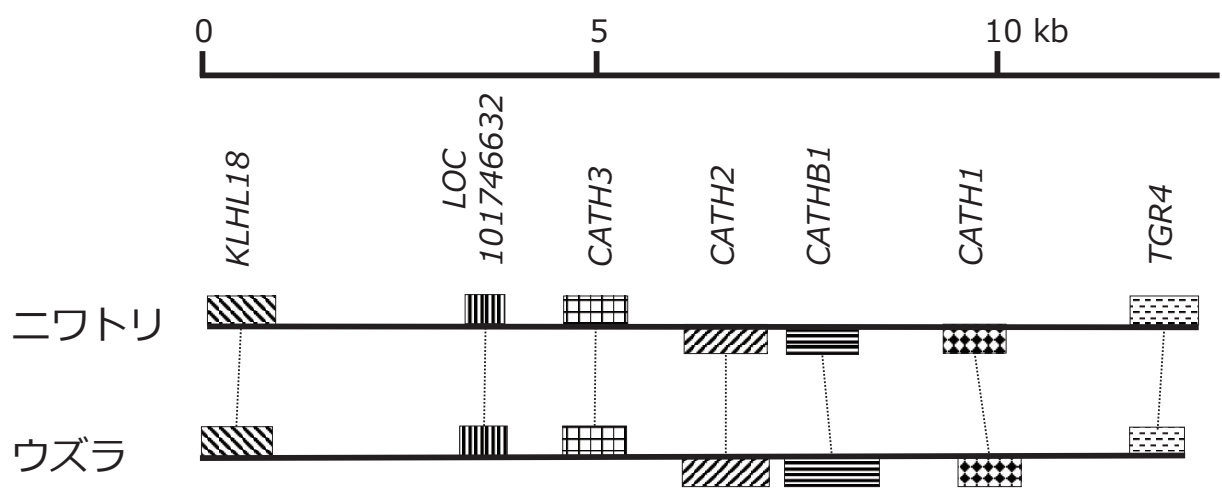

図 2 ニワトリおよびニホンウズラ CATH 領域の遺伝子構成。破線はオルソログを示す。上側に位置する遺伝子はプラス鎖、 下側に位置する遺伝子はマイナス鎖である。ニワトリとニホンウズラの CATH 領域は同じ遺伝子順序および転写方向で保 存されている。

微生物の表面にあるリポポリサッカライドおよびリポ タイコ酸のような負に荷電した分子および負に荷電し た疎水性構造である微生物膜の脂質に結合するために 両親媒性の構造を保持する（Zhang と Sunkara 2014）。 CATH は、他の HDP と同様にグラム陰性・陽性菌、 真菌、原生生物㧍よび一部のウィルスに対して活性を 示す（表 1）（Robyと Nardo 2013; Ageitos ら 2016）。 CATH の多様性については、カエル、ヒト抢よびバッ ファローで多型、ウシで $\mathrm{CNV}$ が報告されている（Yu ら 2013; López ら 2014; Brahma ら 2015; Chen ら 2017)。 しかし、これらの多型や CNV が機能に影響を与える かは未だに不明である（表 1）。

一方で、14 種の鳥類で $C A T H$ が、報告されている (Cheng ら 2015)。ニワトリではCATH1、CATH2、 CATH3 および CATHB1 の 4 つの CATH がタンデムに 座位する $C A T H$ 領域が報告されている（図 2）（Cheng ら 2015)。ニワトリ、ヨーロッパウズラおよびハトの CATH は、ほ乳類と同様に骨䯣や上皮細胞で発現する (Zhang と Sunkara 2014)。鳥類の CATH は、グラム陰性・ 陽性菌抏よび真菌に対して抗菌活性を示す（Zhang と Sunkara 2014; Gao ら 2015; Yu ら 2015)。鳥類では CATH の多型に関する報告はない。

我々の研究では、ニホンウズラ 5 個体は他のキジ科 鳥類と同様に 4 種の $C A T H$ 遺伝子がタンデムに並んで いる（図 2）（Ishige ら 2017）。驚くべきことに、 $C A T H 3$ の抗菌活性領域は、ニホンウズラとニワトリ で完全に一致していた。さらに、 $\mathrm{CATH} 2$ 打よび CATHB 1 にはペプチドの機能に影響を与えるアミノ 酸置換が確認された (Ishige ら 2017)。以上のことから、 CATH は各遺伝子座により多型性が異なり、確認され
たアミノ酸置換が抗菌活性に影響を与えることが示唆 された。

\section{2-4. Defensin}

HDP の 1つである defensin（以下 DEF と記載）は、 䣲母、植物、昆虫、魚類、鳥類およびほ乳類などで報 告されており（表 1)、まさにHDP の代表格とも呼ぶ に相応しいペプチドである。DEF の特徴は、システ イン、アルギニンおよび芳香族アミノ酸に富み、シス テインによるジスルフィド結合により $\beta$ シート構造を 含む $30-45$ アミノ酸残基のペプチドである (Hemshekhar ら 2016)。DEF は、多くの動物の常染色 体上にクラスターを形成し、ヒトやマウスでは 30 種 類の DEF が報告されている。DEF は、 $\alpha$ （DEFA）、 $\beta$ （DEFB）㧍よび $\theta$ (DEFT) の 3 タイプに分類され、 主に好中球、上皮細胞で合成・分泌される（Hemshekhar ら 2016)。DEFTを除いて、他の HDP と同様に、シグ ナルペプチド、プロピース、成熟ペプチドからなる。 これら 3 タイプは、6つのシステイン残基のジスル フィド結合の架橋により明確に分類される。DEFA は $\mathrm{N}$ 末端から数えて 1 番目のシステイン残基と 6 番目の システイン残基（C1-C6）間、同様に C2-C5、C3-C4 間でジスルフィド結合する。 DEFB は C1-C5、C2-4、 C3-6 間でジスルフィド結合する。一方で、DEFT は環 状構造を持つ極めてユニークな DEFである。DEFT は $\alpha$-defensin-related peptide 前駆体からプロセスされ た 2 種類の DEF 分子が 3 個のジスルフィド結合した 後に末端を切り出し、末端を結合した環状構造を取る。 これら 3 つの DEF の中で最古の DEF は DEFB である。 なぜなら、DEFA は鳥類以下では確認されず、DEFT 


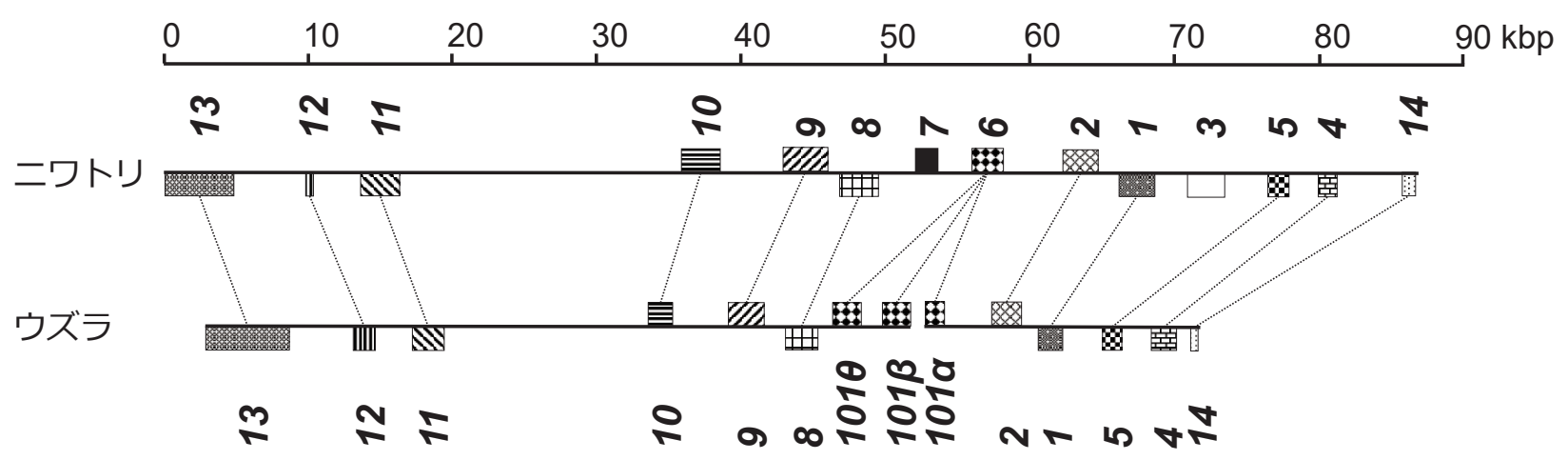

図 3 ニワトリおよびニホンウズラの AvBD 領域。破線はオルソログを示す。各数字は AvBD の種類を示す。上側に位置する 遺伝子はプラス鎖、下側に位置する遺伝子はマイナス鎖である。ニワトリとニホンウズラの遺伝子の向き、順序は一致する。 しかし、ニホンウズラはAvBD3 および 7 の久損、AvBD6（ウズラでは AvBD101 と命名）のオルソログに 3 個の重複が起 きている。

は霊長類のみ（ヒトでは偽遺伝子）である。しかし、 DEFB はウシ、ブタを含むほ乳類や鳥類でも報告され て抢り、このことから最古の DEF と考えられている。 DEF は、その他の HDP と同様に微生物、真菌、原生 生物㧍よびゥイルスに対して活性を示す（表 1) (Bagnicka ら 2010; Hemshekhar ら 2016)。

DEFでは、多型拉よび CNV が報告されている (Bagnicka ら 2010; Lee ら 2016)。ヒトの DEFB の多型 は、Helicobacter pylori に誘導される胃炎、HIV および その他多くの感染症、ハンセン病、皮膚炎、乾痽、ク ローン病、前立腺癌、口腔扁平上皮癌、メラノーマお よび糖尿病の感受性と関係があることが報告されてい る (Bagnicka ら 2010)。ニワトリの AvBD では、多型 によりサルモネら感染への抵抗性に影響を与えること が報告されている（Bagnicka ら 2010）。また、ウシに おいても多型が報告されている（Bagnicka ら 2010）。 DEFの CNV は、ヒト (Incani ら 2016)、ウシ (Meade ら 2014)、イヌ (Leonard ら 2012) およびニワトリ（Lee ら 2016）で報告されている。特に、ヒトの DEFA お よびDEFB の CNVは、IgA 腎症打よび腎機能障害 (Ai ら 2016)、アルッハイマー病（Szekeres ら 2016）、尿 路感染 (Schwaderer ら 2016) のような病気との関連 が報告されている。このため、DEFの多型抒よび $\mathrm{CNV}$ はこれら疾患の進展・発症の個体差要因の可能 性が有るのではないかと示唆されている。

一方、53種の鳥類でAvBDが、報告されている (Cheng ら 2015)。ニワトリでは 14 種の $A v B D$ 遺伝子がタンデ ムに座位する $A v B D$ 領域が報告されている(図 3) (Xiao ら 2004)。AvBD は、ほ乳類と同様に骨髄や上皮細胞 で発現する (Achanta ら 2012)。鳥類の AvBDは、グ ラム陰性・陽性菌、真菌および一部のウイルスに対し
て抗菌活性を示す（Cuperus ら 2013）。また、免疫調 節機能についても報告されている (Soman ら 2009a、b)。 多様性については、ニワトリ、シジュウカラおよびセー シェルヤブセンニュウで多型または CNV が報告され ている (Hasenstein と Lamont 2007; Hellgren 2015; Gilroy ら 2016; Lee ら 2016)。ニワトリはAvBD11、12 抢よび 13 の多型により Salmonella Enteritidis 感染の抵 抗性が異なるため、マーカー遺伝子となる可能性が示 唆されている (Hasenstein と Lamont ら 2007)。また、 シジュウカラ $A v B D 2 、 4 、 7 、 9 、 10$ および 12 の非同 義置換は、疎水性㧍よび実効電荷に影響を与えること から、病原微生物への結合に影響を与えると考えられ ている (Hellgren 2015)。さらに、種により久損 $(A v B D 2 、$ 3、4、5、7、11、12、13 および 14）抒よび偽遺伝子 化 (AvBD1、7、9、11 および 14) が確認されている (Cheng ら 2015）が、報告されているゲノム情報は次世代シー ケンサーにより作成されたドラフトゲノムが多く、そ の精度には注意が必要である。

我々の研究では、まずニホンウズラの AvBD 領域の 塩基配列を決定した（Ishige ら 2016b）。ニワトリと比 較したところ、他の鳥類でも確認されている $A v B D 3$ および 7 の欠損（図 3)、AvBD6 に相当する $A v B D 101$ に扔ける 3 個の CNV が確認された（図 3)。これらの ことが、ニホンウズラの抗病性に影響を与える要因で はないかと示唆された。

\section{おわりに}

本稿では、鳥類の HDP の多様性について、HDP の 概要と鳥類に扔ける多様性を我々の研究を交えて紹介 した。現在、多くの鳥類でドラフトシーケンスが公開 されているが、HDP は未同定もしくは一部同定であ 
ることがよく見受けられる。特に $C A T H$ や $A v B D$ のよ うにクラスターを形成するものの同定が進んでいない ように思われる。HDP は遺伝子重複によりその数を 増やしていったために、クラスターを形成する HDP 遺伝子は抢互いが非常に高い類似性を示している。次 世代シーケンサーを利用した全ゲノム de novo アセン ブルでは、シークエンス長が短いこと（イルミナ次世 代シーケンサーの場合は長くても 300bp）と HDP 遺 伝子間の類似性は高いために現行のソフトでの解析は 非常に難しいのではないかと考えられる。このため、 我々が取ったような部分的に増幅する Long Range PCR 用いた amplicon sequence、またはPacific Bioscience 社の RS II / Sequel システムおよび Oxford Nanopore Technologies 社の MinIon のロングリードシー ケンサーで解析することがポイントになると考えられ る。我々が解析したニホンウズラは同一サンプルを用 いて解析した。興味深いことにLEAP-2 のように多様 性がないものがある一方で、NKL および一部の CATH に機能に影響を与えるアミノ酸置換が推定された。ま た、AvBDに関しては遺伝子座の重複や久損が確認さ れた。いずれにしても、ヒトの HDP 研究において、 そのアミノ酸置換や $\mathrm{CNV}$ が疾患への罹患率に関わっ てくることは明白であり、家畜の抗病性育種を考える 上でHDP は無視できないと考えられる。そのため、 HDP の研究が、いつの日か家畜への抗病性育種に生 かせる日が来ることを切に願っている。

\section{謝辞}

本稿で紹介したニホンウズラ HDP の解析は、東京 農業大学先端研究「遺伝子発現機構に基づく新たな家 畜改良に関する研究」、私立大学戦略的研究基盤形成 支援事業「革新的ゲノム解析情報を用いた生物資源ゲ ノム解析と農学新領域の創出」および「生命科学と情 報科学の融合による農学研究の拠点形成」による支援 を受け行われた。ここに感謝いたします。

\section{文献}

Achanta M, Sunkara LT, Dai G, Bommineni YR, Jiang W, Zhang G. 2012. Tissue expression and developmental regulation of chicken cathelicidin antimicrobial peptides. Journal of Animal Science and Biotechnology, 3: 1-7.

Ageitos JM, Sánchez-Pérez A, Calo-Mata P, Villa TG. 2016. Antimicrobial peptides (AMPs): Ancient compounds that represent novel weapons in the fight against bacteria. Biochemical Pharmacology, 133: 117-138.
Ai Z, Li M, Liu W, Foo JN, Mansouri O, Yin P, Zhou Q, Tang X, Dong X, Feng S, Xu R, Zhong Z, Chen J, Wan J, Lou T, Yu J, Zhou Q, Fan J, Mao H, Gale D, Barratt J, Armour JA, Liu J, Yu X. 2016. Low a -defensin gene copy number increases the risk for IgA nephropathy and renal dysfunction. Science Translational Medicine, 8: 345-388.

Andersson M, Gunne H, Agerberth B, Boman A, Bergman T, Sillard R, Jörnvall H, Mutt V, Olsson B, Wigzell H. 1995. NK-lysin, a novel effector peptide of cytotoxic $\mathrm{T}$ and NK cells. Structure and cDNA cloning of the porcine form, induction by interleukin 2, antibacterial and antitumour activity. The EMBO Journal, 14: 1615-1625.

Bagnicka E, Strzałkowska N, Jóźwik A, Krzyżewski J, Horbańczuk J, Zwierzchowski L. 2010. Expression and polymorphism of defensins in farm animals. Acta Biochimica Polonica, 57: 487-497.

Brahma B, Patra MC, Karri S, Chopra M, Mishra P, De BC, Kumar S, Mahanty S, Thakur K, Poluri KM, Datta TK, De S. 2015. Diversity, antimicrobial action and structure-activity relationship of buffalo Cathelicidins. PloS One, 10: 1-21.

Bruhn H, Riekens B, Berninghausen O, Leippe M. 2003. Amoebapores and NK-lysin, members of a class of structurally distinct antimicrobial and cytolytic peptides from protozoa and mammals: a comparative functional analysis. Biochemical Journal, 375: 737-744.

Chen J, Huddleston J, Buckley RM, Malig M, Lawhon SD, Skow LC, Lee MO, Eichler EE, Anderson L, Womack JE. 2015. Bovine NK-lysin: Copy number variation and functional diversification. Proceedings of the National Academy of Sciences of the United States of America, 112: E7223-E7229.

Chen L, Chamberlain AJ, Reich CM, Daetwyler HD, Hayes BJ. 2017. Detection and validation of structural variations in bovine whole-genome sequence data. Genetics Selection Evolution, 49: 1-13.

Cheng Y, Prickett MD, Gutowska W, Kuo R, Belov K, Burt DW. 2015. Evolution of the avian $\beta$-defensin and cathelicidin genes. BMC Evolutionary Biology, 15: 1-17.

Cuperus T, Coorens M, van Dijk A, Haagsman, HP. 2013. Avian host defense peptides. Developmental \& Comparative Immunology, 41: 352-369.

Dalloul RA, Long JA, Zimin AV, Aslam L, Beal K, Ann BL, Bouffard P, Burt DW, Crasta O, Crooijmans RP, Cooper K, Coulombe RA, De S, Delany ME, Dodgson JB, 
Dong JJ, Evans C, Frederickson KM, Flicek P, Florea L, Folkerts O, Groenen MA, Harkins TT, Herrero J, Hoffmann S, Megens HJ, Jiang A, de Jong P, Kaiser P, Kim H, Kim KW, Kim S, Langenberger D, Lee MK, Lee T, Mane S, Marcais G, Marz M, McElroy AP, Modise T, Nefedov M, Notredame C, Paton IR, Payne WS, Pertea G, Prickett D, Puiu D, Qioa D, Raineri E, Ruffier M, Salzberg SL, Schatz MC, Scheuring C, Schmidt CJ, Schroeder S, Searle SM, Smith EJ, Smith J, Sonstegard TS, Stadler PF, Tafer H, Tu ZJ, Van Tassell CP, Vilella AJ, Williams KP, Yorke JA, Zhang L, Zhang HB, Zhang X, Zhang Y, Reed KM. 2010. Multiplatform next-generation sequencing of the domestic turkey (Meleagris gallopavo): genome assembly and analysis. PLoS Biology, 8: 1-21.

Davis EG, Sang Y, Rush B, Zhang G, Blecha F. 2005. Molecular cloning and characterization of equine NK-1ysin. Veterinary Immunology and Immunopathology, 105: 163-169.

Deng A, Chen S, Li Q, Lyu, SC, Clayberger C, Krensky AM. 2005. Granulysin, a cytolytic molecule, is also a chemoattractant and proinflammatory activator. The Journal of Immunology, 174: 5243-5248.

E1 Karim IA, Linden GJ, Orr DF, Lundy FT. 2008. Antimicrobial activity of neuropeptides against a range of micro-organisms from skin, oral, respiratory and gastrointestinal tract sites. Journal of Neuroimmunology, 200: 11-16.

Endsley JJ, Furrer JL, Endsley MA, McIntosh MA, Maue AC, Waters WR, Lee DR, Estes DM. 2004. Characterization of bovine homologues of granulysin and NK-lysin. The Journal of Immunology, 173: 2607-2614.

Ernst WA, Thoma-Uszynski S, Teitelbaum R, Ko C, Hanson DA, Clayberger C, Krensky AM, Leippe M, Bloom BR, Ganz T, Modlin RL. 2000. Granulysin, a T cell product, kills bacteria by altering membrane permeability. The Journal of Immunology, 165: 7102-7108.

Epand RM, Vogel HJ. 1999. Diversity of antimicrobial peptides and their mechanisms of action. Biochimica et Biophysica Acta (BBA)-Biomembranes, 1462: 11-28.

Gao W, Xing L, Qu P, Tan T, Yang N, Li D, Chen H, Feng X. 2015. Identification of a novel cathelicidin antimicrobial peptide from ducks and determination of its functional activity and antibacterial mechanism. Scientific Reports, 5: 1-12.

Gilroy D, Oosterhout C, Komdeur J, Richardson DS. 2016.
Avian $\beta$-defensin variation in bottlenecked populations: the Seychelles warbler and other congeners. Conservation Genetics, 17: 661-674.

Hancock RE. 2001. Cationic peptides: effectors in innate immunity and novel antimicrobials. The Lancet Infectious Diseases, 1: 156-164.

Harwig SS, Tan L, Qu XD, Cho Y, Eisenhauer PB, Lehrer RI. 1995. Bactericidal properties of murine intestinal phospholipase A2. Journal of Clinical Investigation, 95: 603-610.

Hasenstein JR, Lamont SJ. 2007. Chicken gallinacin gene cluster associated with Salmonella response in advanced intercross line. Avian Diseases, 51: 561-567.

Hellgren O. 2015. Allelic variation at innate immune genes (avian $\beta$-defensins), within a natural population of great tits. Journal of Avian Biology, 46: 113-118.

Hemshekhar M, Anaparti V, Mookherjee N. 2016. Functions of cationic host defense peptides in immunity. Pharmaceuticals, 9: 1-10.

Hong YH, Lillehoj HS, Dalloul RA, Min W, Miska KB, Tuo W, Lee SH, Han JY, Lillehoj EP. 2006. Molecular cloning and characterization of chicken NK-lysin. Veterinary Immunology and Immunopathology, 110: 339-34

Ishige T, Hara H, Hirano T, Kono T, Hanzawa K. 2014. Basic characterization of avian NK - lysin (NKL) from the Japanese quail, Coturnix japonica. Animal Science Journal, 851: 90-95.

Ishige T, Hara H, Hirano T, Kono T, Hanzawa K. 2016a. Effect of a single polymorphism in the Japanese quail NK - lysin gene on antimicrobial activity. Animal Science Journal, 87: 143-146.

Ishige T, Hara H, Hirano T, Mannen H, Kono T, Hanzawa K. 2016b. Basic characterization of avian $\beta$ - defensin genes in the Japanese quail, Coturnix japonica. Animal Science Journal, 87: 311-320.

Ishige T, Hara H, Hirano T, Kono T, Hanzawa K. 2016c. Characterization and expression of non - polymorphic liver expressed antimicrobial peptide 2: LEAP - 2 in the Japanese quail, Coturnix japonica. Animal Science Journal, 87: 1182-1187.

Ishige T, Hara H, Hirano T, Kono T, Hanzawa K. 2017. Characterization of the cathelicidin cluster in the Japanese quail (Coturnix japonica). Animal Science Journal, 88: 1249-1257.

Incani F, Cossu C, Meloni A, Faà V, Serra ML, Dettori F, Meloni A, Rosatelli MC. 2016. $\beta$ - defensin CNV is 
not associated with susceptibility to Candida albicans infections in Sardinian APS I patients. Journal of Oral Pathology \& Medicine, 46: 393-397.

Kim WH, Lillehoj HS, Gay CG. 2016. Using genomics to identify novel antimicrobials. Revue Scientifique et Technique (International Office of Epizootics), 35: 95-103.

Krause A, Sillard R, Kleemeier B, Klüver E, Maronde E, Conejo - García J.R, Forssmann WG, Schulz-Knappe P, Nehls MC, Wattler F, Wattler S, Adermann K. 2003. Isolation and biochemical characterization of LEAP - 2, a novel blood peptide expressed in the liver. Protein Science, 12: 143-152.

Lee MO, Kim EH, Jang HJ, Park MN, Woo HJ, Han JY, Womack JE. 2012. Effects of a single nucleotide polymorphism in the chicken NK-lysin gene on antimicrobial activity and cytotoxicity of cancer cells. Proceedings of the National Academy of Sciences of the United States of America, 109: 12087-12092.

Lee MO, Bornelöv S, Andersson L, Lamont SJ, Chen J, Womack JE. 2016. Duplication of chicken defensin7 gene generated by gene conversion and homologous recombination. Proceedings of the National Academy of Sciences of the United States of America, 113: 13815-13820.

Leonard BC, Marks SL, Outerbridge CA, Affolter VK, Kananurak A, Young A, Moore PF, Bannasch DL, Bevins CL. 2012. Activity, expression and genetic variation of canine $\beta$-defensin 103: a multifunctional antimicrobial peptide in the skin of domestic dogs. Journal of Innate Immunity, 4: 248-259.

Li HX, Lu XJ, Li CH, Chen J. 2015. Molecular characterization of the liver-expressed antimicrobial peptide 2 (LEAP-2) in a teleost fish, Plecoglossus altivelis: Antimicrobial activity and molecular mechanism. Molecular Immunology, 65: 406-415.

Liu F, Li JL, Yue GH, Fu JJ, Zhou ZF. 2010. Molecular cloning and expression analysis of the liver-expressed antimicrobial peptide 2 (LEAP-2) gene in grass carp. Veterinary Immunology and Immunopathology, 133: 133-143.

López Campos GN, Velarde Félix JS, Sandoval Ramírez L, Cázares Salazar S, Corona Nakamura AL, Amaya Tapia G, Prado Montes de Oca E. 2014. Polymorphism in cathelicidin gene (CAMP) that alters Hypoxia-inducible factor (HIF-1 $a$ ::ARNT) binding is not associated with tuberculosis. International Journal of Immunogenetics, 41: 54-62.

Ma LL, Spurrell JC, Wang JF, Neely GG, Epelman S,
Krensky AM, Mody CH. 2002. CD8 T cell-mediated killing of Cryptococcus neoformans requires granulysin and is dependent on CD4 T cells and IL-15. The Journal of Immunology, 169: 5787-5795.

Mahlapuu M, Håkansson J, Ringstad L, Björn C. 2016. Antimicrobial Peptides: An Emerging Category of Therapeutic Agents. Frontiers in Cellular and Infection Microbiology, 6: 1-12.

Meade KG, Cormican P, Narciandi F, Lloyd A, O’ Farrelly C. 2014. Bovine $\beta$-defensin gene family: opportunities to improve animal health? Physiological Genomics, 46: 17-28.

Ochoa MT, Stenger S, Sieling PA, Thoma-Uszynski S, Sabet S, Cho S, Krensky AM, Rollinghoff M, Nunes Sarno E, Burdick AE, Rea TH, Modlin RL. 2001. T-cell release of granulysin contributes to host defense in leprosy. Nature Medicine, 7: 174-179.

Peña SV, Krensky AM. 1997. Granulysin, a new human cytolytic granule-associated protein with possible involvement in cell-mediated cytotoxicity. In Seminars in Immunology, 9: 117-125

Roby KD, Nardo AD. 2013. Innate immunity and the role of the antimicrobial peptide cathelicidin in inflammatory skin disease. Drug Discovery Today: Disease Mechanisms, 10: e79-e82.

Schwaderer AL, Wang H, Kim S, Kline JM, Liang D, Brophy PD, McHugh KM, Tseng GC, Saxena V, BarrBeare E, Pierce KR, Shaikh N, Manak JR, Cohen DM, Becknell B, Spencer JD, Baker PB, Yu CY, Hains DS. 2016. Polymorphisms in $a$-Defensin-Encoding DEFA1A3 Associate with Urinary Tract Infection Risk in Children with Vesicoureteral Reflux. Journal of the American Society of Nephrology, 27: 3175-3186.

Soman SS, Arathy DS, Sreekumar E. 2009a. Discovery of Anas platyrhynchos avian $\beta$-defensin 2 (Apl_AvBD2) with antibacterial and chemotactic functions. Molecular Immunology, 46: 2029-2038.

Soman SS, Nair S, Issac A, Arathy DS, Niyas KP, Anoop M, Sreekumar E. 2009b. Immunomodulation by duck defensin, Apl_AvBD2: In vitro dendritic cell immunoreceptor (DCIR) mRNA suppression, and B-and T-lymphocyte chemotaxis. Molecular Immunology, 46: 3070-3075.

Stenger S, Mazzaccaro RJ, Uyemura K, Cho S, Barnes PF, Rosat JP, Sette A, Brenner MB, Porcelli SA, Bloom BR, Modlin RL. 1997. Differential effects of cytolytic T cell subsets on intracellular infection. Science, 276: 1684-1687. 
Szekeres M, Ivitz E, Datki Z, Kálmán J, Pákáski M, Várhelyi ZP, Klivényi P, Zadori D, Somogyvári F, Szolnoki Z, Vécsei L, Mándi Y. 2016. Relevance of defensin $\beta-2$ and $\alpha$ defensins (HNP1-3) in Alzheimer' s disease. Psychiatry Research, 239: 342-345.

Takamori Y, Ogawa K, Nagata K, Nakamura M. 2005. Granulysin induces cell death with nuclear accumulation. Journal of Medical and Dental Sciences, 52: 1-7.

Townes CL, Michailidis G, Hall J. 2009. The interaction of the antimicrobial peptide cLEAP-2 and the bacterial membrane. Biochemical and Biophysical Research Communications, 387: 500-503.

Wang Q, Wang Y, Xu P, Liu Z. 2006. NK-lysin of channel catfish: gene triplication, sequence variation, and expression analysis. Molecular Immunology, 43: 1676-1686.

Warren WC, Clayton DF, Ellegren H, Arnold AP, Hillier LW, Künstner A, Searle S, White S, Vilella AJ, Fairley S, Heger A, Kong L, Ponting CP, Jarvis ED, Mello CV, Minx P, Lovell P, Velho TA, Ferris M, Balakrishnan CN, Sinha S, Blatti C, London SE, Li Y, Lin YC, George J, Sweedler J, Southey B, Gunaratne P, Watson M, Nam K, Backström N, Smeds L, Nabholz B, Itoh Y, Whitney O, Pfenning AR, Howard J, Völker M, Skinner BM, Griffin DK, Ye L, McLaren WM, Flicek P, Quesada V, Velasco G, Lopez-Otin C, Puente XS, Olender T, Lancet
D, Smit AF, Hubley R, Konkel MK, Walker JA, Batzer MA, Gu W, Pollock DD, Chen L, Cheng Z, Eichler EE, Stapley J, Slate J, Ekblom R, Birkhead T, Burke T, Burt D, Scharff C, Adam I, Richard H, Sultan M, Soldatov A, Lehrach H, Edwards SV, Yang SP, Li X, Graves T, Fulton L, Nelson J, Chinwalla A, Hou S, Mardis ER, Wilson RK. 2010. The genome of a songbird. Nature, 464: 757-762.

Xiao Y, Hughes AL, Ando J, Matsuda Y, Cheng JF, SkinnerNoble D, Zhang G. 2004. A genome-wide screen identifies a single $\beta$-defensin gene cluster in the chicken: implications for the origin and evolution of mammalian defensins. BMC Genomics, 5: 1-11.

Yu H, Cai S, Gao J, Zhang S, Lu Y, Qiao X, Yang H, Wang Y. 2013. Identification and polymorphism discovery of the cathelicidins, Lf - CATHs in ranid amphibian (Limnonectes fragilis). FEBS Journal, 280: 6022-6032.

Yu H, Lu Y, Qiao X, Wei L, Fu T, Cai S, Wang C, Liu X, Zhong S, Wang Y. 2015. Novel cathelicidins from pigeon highlights evolutionary convergence in avain cathelicidins and functions in modulation of innate immunity. Scientific Reports, 5: 1-13.

Zhang G, Sunkara LT. 2014. Avian antimicrobial host defense peptides: from biology to therapeutic applications. Pharmaceuticals, 7: 220-247. 